\title{
The Employment of Older People: Can We Learn from Japan?"
}

\author{
Bernard H. Casey \\ The Pensions Institute, Cass Business School, City University, 106 Bunhill Row, London EC1Y 8TZ, U.K. \\ E-mail: b.casey@city.ac.uk
}

The level of employment among older people, including those above retirement age is very high in Japan. This has been attributed to the lifetime employment system, and provisions for external transfers and demotions that allow wages to be reduced as people pass middle age. The paper points to how the structure of Japanese industry is also important and how many older Japanese are working in relatively unproductive and sheltered jobs. Moreover, it questions whether the lifetime employment system can survive, and shows how early retirement schemes, similar to those in the west, are being introduced as a response to continued recession. On top of this, external pressures for deregulation are threatening the ability of protected sectors to absorb older people. Japanese employers have a tendency, as do western employers, to discard older people. All employers will, in the face of population ageing, have to learn how to use older people better.

The Geneva Papers (2005) 30, 620-637. doi:10.1057/palgrave.gpp.2510051

Keywords: Japan; older workers; employment; retirement; pensions; labour market policy

\section{Introduction}

Japan is frequently remarked upon for its very high level of labour force participation among older workers and particularly older men. In the year 2000, nearly 95 per cent of men aged 55-59 years, nearly three-quarters of those aged 60-64 years and a third of those aged over 65 years were still economically active. Almost all of the economically active were working rather than being unemployed: the relevant employment rates were 90, 63 and 33 per cent, respectively. ${ }^{1}$ A brief comparison with other countries is given in Chart 1.

The very high employment rates exist alongside a relatively low mandatory retirement age operated in many sectors of the economy - 60 years, having risen from 55 years over the past 30 years. They also exist alongside a payment system that makes older workers relatively more expensive. The "lifetime employment" system sets pay according to seniority and thus, effectively, in accordance with age. This paper asks why, under these circumstances, and given the relatively poor performance of the Japanese economy over

\footnotetext{
* A much earlier version of this paper was presented at the Workshop on Ageing, Skills and Labour Markets, organized by CEPII and held in Nantes, September 7-8, 2001. Later versions were given at the conference Pressure, Policy-Making and Policy Outcome - Understanding East Asian Welfare Reforms, organised by East Asia Social Policy Research Network and held at the University of Kent, June 30July 2, 2005 and at the seminar on the Employability of Older Workers, sponsored by the organised ESRC and held in London, September 9, 2005.

${ }^{1}$ Almost all the data in this article refer to men. The employment rates of older women are also high in Japan, although in both Sweden and the USA they are at least as high if not higher.
} 


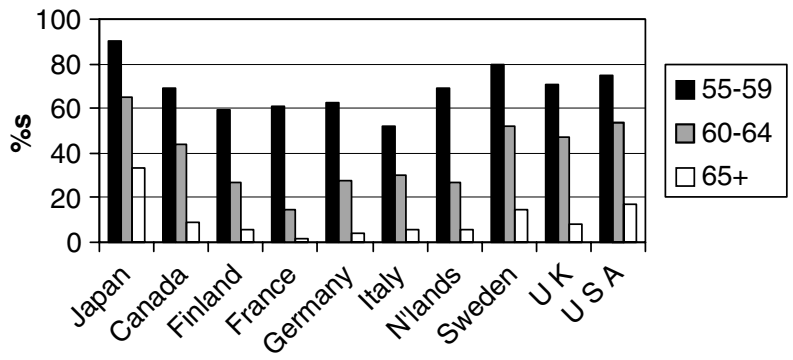

Chart 1. Employment rates for older men, $2000(\% \mathrm{~s})$. Source: OECD.

the past decade, such high rates of employment have been maintained. It then goes on to ask whether they are likely to be maintained in the future.

\section{Some conventional, and some less conventional explanations}

The lifetime employment system has its roots in a mixture of culture and late industrialization. According to some commentators, it resulted from industrial workers being recruited from rural communities and moved from being the dependent members of one closed community to the dependent members of another. The firm replicated many of the practices of the village, particularly in having no concept of an individual job - and so of individual pay - but rather a concept of cooperative work ${ }^{2}$ - and so of pay according to the type of worker. Within the firm, wage differentials between men and women were perpetuated, but pay also reflected assumed responsibilities, and these were recognized as rising with age. ${ }^{3}$ According to other commentators, the lifetime employment system was a rational response to labour shortages in periods of rapid growth, and it was a way by which firms sought to reduce turnover among skilled workers. It first manifested itself in the 1920s but it did not gain importance until the 1950s. ${ }^{4}$ Whatever the origins of the system, many observers have pointed out how "compared to (countries for which equivalent data is available), the age-earnings profile of Japanese workers remains steeper over a longer time period". 5

Precisely because of this pronounced age-earnings profile, firms impose mandatory retirement, ${ }^{6}$ and retirement is presumed to occur a few years after domestic responsibilities have peaked. A mandatory retirement age is operated by almost all large firms and by most but the very smallest ones. Its level has been set by employers, or by collective agreements, but increases have been encouraged by the government that has sought to keep it aligned with the age of eligibility of a public pension. The

\footnotetext{
${ }^{2}$ This is associated with a high degree of job flexibility that, in turn, has been used to explain high levels of productivity, see Koike (1997).

3 Sano (1997).

${ }^{4}$ Matsuzuka (2002).

${ }^{5}$ OECD (1996, p. 105).

${ }^{6}$ This is a classic case of "why there is mandatory retirement". For an exposition, see Lazear (1979).
} 
latter has, effectively, been 60 years, but since the mid-1990s various steps have been taken to raise it to 65 years. Under current legislation, however, this will not be achieved until 2013 for men and 2018 for women. ${ }^{7}$ The earlier, upward movement of the mandatory retirement age that occurred in the 1980s and 1990s was matched by an upward movement of the age at which earnings peaked. In 1980, this stood at around 52 years, in 1999 at around 57 years. $^{8}$

The practices of employers that allow some of the consequences of an age-related payment system and the associated mandatory retirement age to be circumvented are suggested to be an important reason as to why the rate of employment amongst older people is high. Many employers offer forms of re-employment to those reaching mandatory retirement age. Such re-employment is often on a temporary basis, and it might involve a change in terms and conditions. Amongst firms with a retirement age under 65 , the proportion offering continued employment until that age has now reached 55 per cent, although only a quarter of these firms give a job to all those who apply for one.

Frequently referred to is the practice by which employees who are in their mid-50s are moved from their career jobs to jobs with subcontracting firms under arrangements such as shukko and tenseki. Shukko is a practice by which the transferred worker remains an employee of the sending firm, tenseki is a practice by which the transferred worker becomes an employee of the receiving firm. A period of transfer on shukko can be followed by a termination of the original contract and re-employment upon tenseki. ${ }^{10}$

Where there is no re-employment opportunity, and no opportunity for transfer, the employing firm might use its best efforts to assist in finding subsequent work or even help departing employees - who will receive a lump-sum retirement payment - to establish themselves in self-employment. ${ }^{11}$

The change in job, employment status and/or employer in later life is usually associated with some form of wage reduction. Thus, the age-wage curve shifts sharply downwards after having reached its peak, but more than in many other countries. ${ }^{12}$ Among those who stay with their old firm, the average wage reduction is estimated to be some 30 per cent; among those who change employer, it is close to 50 per cent. $^{13}$

${ }^{7}$ The Japanese public pension has two tiers - a basic, flat-rate tier and an earnings-related tier worth, respectively, some 18 per cent and some 30 per cent of gross average earnings. The basic pension has, since the early 1950 s, been available only at 65 years, but the full earnings-related pension could be drawn at 60 years. Those who ceased working completely at 60 years were eligible for a supplement to the earningsrelated pension that was the equivalent of the basic pension. However, this supplement was phased out gradually after 1994 and ceased applying at all after 2000 (see Casey (2004)).

8 JIL (2000).

${ }^{9}$ See OECD (2004). The data refer to private sector enterprises with at least 30 employees.

${ }^{10}$ Sato (1996).

${ }^{11}$ Rebick (1995).

${ }^{12}$ Most age-wage curves are cross-sectional and do not show the development of cohorts, let alone individuals. Thus, they seldom show how individuals' wages progress with age, and they cannot capture any changes associated with changes in the nature of the jobs that the individuals concerned might experience.

13 JIL (2000). 


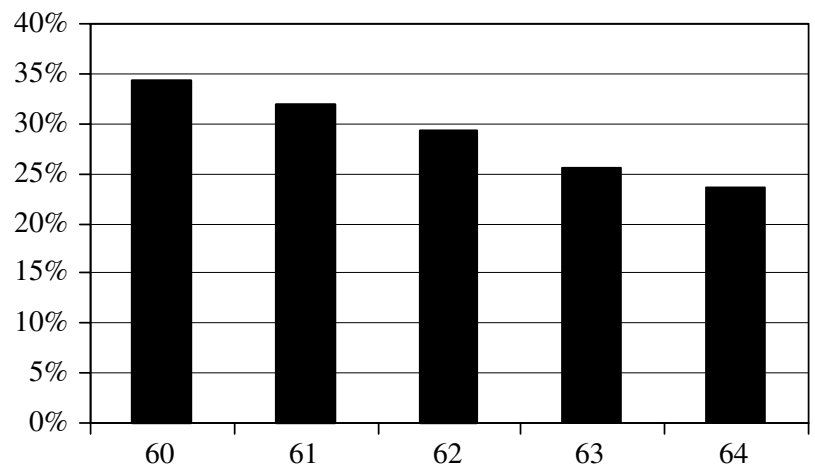

Chart 2. Employment and pension receipt among older men. Source: Social Insurance Agency, Annual Operational Report FY 2000. Note: Includes people whose pension is totally suspended - up to one-quarter.

Total income, however, falls by somewhat less. Under the rules of the public pension system, someone eligible for an earnings-related pension can draw this benefit but go back to work. Until the age of eligibility of the earnings-related pension was lifted to 65 years, this provision applied to people aged 60-64 years. An "earnings test" reduced the pension by at least 20 per cent and by a taper to 100 per cent once earnings exceeded those of the average for an industrial worker. Under these provisions, someone taking a job paying about half the average industrial wage would be able to increase his gross income by about 50 per cent. As Chart 2 shows, about 30 per cent of men aged 60-64 years who were drawing an earnings-related public pension were also working. Since 2002 a further, but somewhat less severe "earnings rule" with respect to the second tier pension has been applied for people working between 65 and 69 years. ${ }^{14}$

Employment practices such as offers of re-employment or a transfer to a subsidiary, together with the ability to combine work with receipt of a pension, constitute only part of the explanation for why older people remain in work beyond the mandatory retirement age. The importance of the lifetime employment system has often been exaggerated. Those who have analysed it closely suggest that it applied to maybe some 20-30 per cent of all employees - full-time, male workers in larger enterprises. ${ }^{15}$ Moreover, as Table 1 shows, in the year 2000, only about one in four men in their late 40s who worked in the private, non-agricultural sector was in an enterprise with 1000 or more employees and fewer than one in three work in one with 500 or more employees. As a proportion of the all men of that age who were at work, these shares fall to a fifth and a quarter.

Small enterprises are somewhat less likely to operate mandatory retirement ages than larger ones. In the mid-1990s, while almost all enterprises with 300 or more employees had a mandatory retirement age, only 72 per cent of those with between 10 and 29 employees, and only 31 per cent of those with under 10 employees had one. ${ }^{16}$ In

\footnotetext{
${ }^{14}$ See OECD (2004).

${ }^{15}$ Lincoln (2001).

16 Sato (2000).
} 
Table 1 Employment of men aged 45-49 years by firm size, $2000(\% \mathrm{~s})$

\begin{tabular}{lrr}
\hline & & Men aged 45-49 \\
\hline All & 100 & 3 \\
In the agricultural sector & 2 & 100 \\
Non-agricultural self-employed & 11 & 15 \\
In the government sector & 84 & 28 \\
Private sector employees & 13 & 29 \\
In a firm with $<10$ employees & 24 & 23 \\
In a firm with $<30$ employees & 24 & 19 \\
In a firm with $>499$ employees & 19 & \\
In a firm with $>1000$ employees
\end{tabular}

Source: Management and Co-ordination Agency, Statistics Bureau (2000a), Report on the Special Survey of the Labour Force, February 2000 (Labour Force Series No. 65); own calculations.

addition, small enterprises are more likely than larger enterprises to offer to continue the employment of people who reach mandatory retirement. Thus, some 55 per cent of firms with 10-29 employees did so, compared with 35 per cent of those with 5000 or more employees. Small firms are not, however, any more likely to extend the offer to all who wish to work than are larger enterprises. This means that a substantial proportion of older people receive no structured assistance at all from their employer in finding post-retirement-age work. Obtaining a picture on what happens to them is difficult because most surveys of employer practice do not sample firms with fewer than 30 employee, yet these firms employ about a quarter of all those working in the private sector. It might be expected that, in the small and micro-enterprise sector, personal relationships are such that many employees are retained into older age and few are involuntarily retired.

On the other hand, and as in most countries, conditions in the small-firms sector are markedly inferior to those in the large-firms sector. Pay is lower, coverage by supplementary pension plans is lower, and payment of a lump-sum upon retirement is less frequent. Those older employees who move into the small-firms sector, and who do not continue an employment contract with their career employer, experience a substantial drop in their earnings. Some of this is compensated for by the partial pension they will be able to draw and the severance payments they have received from their former employer. Those older employees who move from one small firm to another, and move without assistance from the previous employer, usually do so without any severance payment and can suffer a significant fall in their income. ${ }^{17}$

An understanding of the role of job transfers and of shifts to new employers throws much light upon why such a high proportion of people in their late 50s and early 60s are still in work. It throws less light upon why such a high proportion of those aged 65 years and over are still in work. To make sense of this, it is necessary to look more closely at what the very oldest workers in Japan actually do. This is done in Table 2.

\footnotetext{
${ }^{17}$ Yamada (2000).
} 
Table 2 Characteristics of older male employment, $2000(\% \mathrm{~s})$

\begin{tabular}{|c|c|c|c|}
\hline & All ages & Aged 55-64 years & Aged 65 years and over \\
\hline Participation rate & 76 & 84 & 33 \\
\hline Employment rate & 72 & 78 & 26 \\
\hline \multicolumn{4}{|l|}{ Of which, working in } \\
\hline Agriculture & 5 & 6 & 31 \\
\hline Construction & 14 & 16 & 14 \\
\hline Retailing & 19 & 17 & 19 \\
\hline Agric, construction or retailing & 37 & 39 & 64 \\
\hline \multicolumn{4}{|l|}{ In Agricultural sector } \\
\hline Self-employed & 76 & 85 & 86 \\
\hline Family worker & 12 & 3 & 10 \\
\hline Part-time & 34 & 30 & 49 \\
\hline \multicolumn{4}{|l|}{ In retailing } \\
\hline Self-employed or family worker & 3 & 6 & 10 \\
\hline \multicolumn{4}{|l|}{ In non-agricultural sector } \\
\hline Self-employed & 11 & 18 & 44 \\
\hline Family worker & 1 & $*$ & 4 \\
\hline Part-time & 6 & 5 & 15 \\
\hline Dispatched worker & 3 & 7 & 15 \\
\hline Temporary or daily & 6 & 7 & 24 \\
\hline Unemployment rate & 5.2 & 7.1 & 3.7 \\
\hline
\end{tabular}

Source: Management and Co-ordination Agency, Statistics Bureau, Report on the Special Survey of the Labour Force, February 2000 (Labour Force Series No. 65), and Annual Report on the Labour Force Survey: 2000; own calculations.

*Less than 0.5 .

Self-employment is clearly important as a means of working beyond 65 years. The rate of self-employment increases steadily by age from 17 per cent for those aged 55-59 years, to 30 per cent for those aged 60-64 years, and to 48 per cent for those aged 65 and older. Taken together with family working (paid or otherwise), in the year 2000, self-employment accounted for nearly two-thirds (62 per cent) of all those at work after 65 years. Also important is part-time working - one in four of those working beyond the age of 65 years do so as part-timers. The agricultural sector accounts for nearly one third of those working beyond 65 years, and most of its older labour force is self-employed or working in the family. The wholesale and retail sectors accounted for one-fifth, and construction for one seventh of those working beyond 64 years. Together, these three sectors account for two thirds of the oldest members of the male workforce, making their over-representation almost two-fold.

Movement into self-employment at the end of a career job, often with the encouragement of the former employer, has already been mentioned. Movements into the wholesale and retail sectors are also common, in particular where there is a family connection. Most important are movements back to the agriculture sector. This reflects the fact that, outside the metropolitan areas, many middle aged agricultural workers are kengyo nouka, or have part-time jobs alongside their industrial jobs. It 
also reflects the fact that others, on retiring from the industrial community, return to the rural community, perpetuating a family link with the land and the small plots that are maintained in the name of the family.

\section{System strains}

For over a decade, the Japanese economy has been suffering from slow growth and the prospect of an ageing labour force. Unemployment, while low by international standards, rose to levels that were high by Japanese standards. As continued poor performance became intolerable, enterprises were obliged to restructure and cut costs. The banking system, in part under government and external pressure, was obliged to be more strict about lending policy, to call in bad loans and to force non-performing firms to close. Finally, the government, again in part under external pressure, started to deregulate important sectors of the economy and thereby to force enterprises to adopt more efficient practices.

The consequence was that those personnel practices and policies that served high growth and an expanding labour force ceased to be appropriate. The lifetime employment system that, together with shukko and tenseki, ensured continued employment opportunities for some older workers no longer functioned as effectively as it once did. Large firms, as well as merely reducing their hiring, started to declare redundancies. Already early in 1993, there was survey evidence that firms were feeling an excess of older (here, aged 45 years and above) clerical and managerial workers and that, in the vast majority of cases, this surplus was structural rather than cyclical. Moreover, the larger the firm, the greater the problem was. ${ }^{18}$ More extreme still, major companies started announcing large-scale redundancies as part of their plans to restructure. ${ }^{19}$ Some of these redundancies were even "involuntary". ${ }^{20}$ In other cases, early retirement opportunities were introduced, offering enhanced early pensions or lump-sum severance payments, sometimes to workers as young as 50 years. ${ }^{21}$ Recently, the incidence of such "un-Japanese" practices has appeared only to grow, as Table 3 illustrates.

What is of interest in Table 3 is the appearance of major motor manufacturing firms in the list. In the last few years, both Nissan and Mazda were taken over by foreign companies. The new managements that were put in place there were not Japanese and were not beholden to Japanese practices. ${ }^{22}$ What they sought to do, when pushing through their restructuring plans, was very much what they were doing when they restructured at home (in France or America). They laid workers off and, in particular, they offered early retirement programmes. And where they did, take up has been high. Companies have reported over-subscription within days and even within hours,

\footnotetext{
18 Sato (1994).

19 Osawa and Kingston (1996).

${ }^{20}$ Araki (1995).

${ }^{21}$ Sato (1994).

${ }^{22}$ See, for example, Ibson (2001). The first, and most well known, of the gaijin was Carlos Gohsan from Renault who took charge of Nissan.
} 
Table 3 Major companies announcing/implementing early retirement plans: press announcements since 1999

\begin{tabular}{|c|c|c|c|}
\hline Company & Sector & Date & Additional details \\
\hline Arabian Oil & Oil refining & $\begin{array}{l}\text { Announced March } \\
2000\end{array}$ & \\
\hline Dainippon ink & Chemicals & 2000-2001 & \\
\hline
\end{tabular}

Fujisawa

Pharmaceutical

Co., Ltd

Window open end

November 04 to mid-January 05

In all, 716 employees, of which 218 were from subsidiaries, applied, part of preparation of merger with Yamanouchi Pharmaceutical Co., Ltd to form Astellas Pharma Inc.

From 2000 to 2003

Japan Energy

Corp.

Oil refining and manufacturing

Showa Shell

Oil refining

Isuzu

Motors

Mazda (of Ford) Motors

Nissan (of

Motors

Renault)

Anritsu

Electronics

Fujitsu

Electronics

Hitachi

Matsushita

Electrical/electronics

(Panasonic)

Mitsubishi

Electonics

Electrical Co.
May 2002

Summer 2001

From 1999 to 2001

Over 2000-2001

March 2000

Plant closures and losses. 2,210 early retirements $(8 \%$ of labour force) plan offered to all over 40 years with at least 10 years service

Plans to cut $3-5 \%$ of labour force each year. Renault has early retirement programme for all aged $57+$ years in France

Offered to regular employees aged from 45 to 59 years, with at least 10 years of service, results 312 leavers (including 57 employees dispatched to other companies)

Voluntary early retirement offered to all aged 45 years and over in Japan. Part of plan to cut global workforce by $21 \%$
Spring 1999

March 2000-2001 and January 2005

Repeated programmes in subsequent years

Seeking 5,000 early retirements as part of plan to cut workforce by 13,000. Also making subcontractors more cost efficient. Further 3000 early retirements sought as of in 2005

Over 2000-2001 Part of $10 \%$ cut in labour force 
The Geneva Papers on Risk and Insurance - Issues and Practice

628

Table 3 (continued)

\begin{tabular}{llll}
\hline Company & Sector & Date & Additional details \\
\hline Sega & Electronics & First-half year 1999 & \\
Toshiba & Electronics & August 2001 & $\begin{array}{l}\text { Voluntary early retirement for } \\
\text { people over 40 years, with severance } \\
\end{array}$ \\
& & $\begin{array}{l}\text { payment of } 2 \frac{1}{2} \text { years pay. Expected } \\
\text { cost of } ¥ 60 \mathrm{bn} \text {. Part of } 10 \% \text { cut in } \\
\text { workforce }\end{array}$
\end{tabular}

Kawasaki Heavy Engineering/steel From mid-2000

In merger talks with NKK (see below)

$\begin{array}{lll}\text { Nippon Steel } & \text { Steel } & 1999-2000 \\ \text { NKK } & \text { Steel } & \\ \text { Japan Tobacco } & \text { Tobacco } & 1999 \text { and again } \\ & & \text { 2003-2004 }\end{array}$

$\begin{array}{ll}\text { Kirin } & \text { Brewing } \\ \begin{array}{l}\text { Snow Brand } \\ \text { Milk }\end{array} & \text { Food processing } \\ \text { JAL } & \text { Air transport } \\ \text { NTT } & \text { Telecommunications }\end{array}$

From 1999 to 2001

In merger talks with Kawasaki 2003-2004

Financial year 1999-2000, cutting $10 \%$ of labour force at home and similar proportion abroad; $2003-$ 2004 workforce reduction of $25 \%$ including early retirement offered to employees aged 40-59 years with minimum 15 years service; take up by 5,800 of eligible 12,000 (had expected only 3,500 )

2000

Spring 2000

September 2000 onwards

1999-2000

Announced mid-1999

Reported October 2004

January 2001
In all, 6,500 volunteers on top of 21,000 job cuts already planned (cutting 17\% of workforce). Offering all employees aged 47-60 years 10 months basic pay plus a retirement allowance

Sold businesses to cover early retirement costs

Major restructuring forced by banks

Seeking voluntary early retirement of 800 workers over 40 years old

Store closures. Requires bank loans to cover early retirement costs 
Table 3 (continued)

\begin{tabular}{|c|c|c|c|}
\hline Company & Sector & Date & Additional details \\
\hline $\begin{array}{l}\text { Seiyu }(38 \% \\
\text { owned by Wall } \\
\text { Mart) }\end{array}$ & Supermarket Chain & $\begin{array}{l}\text { Reported December } \\
2003\end{array}$ & $\begin{array}{l}\text { Voluntary early retirement } \\
\text { programme as part of plan } \\
\text { to reduce staff by } 1,613 \\
\text { (or approx one-fifth) }\end{array}$ \\
\hline $\begin{array}{l}\text { Chiyoda and } \\
\text { Dai-Tokyo }\end{array}$ & Insurance & Spring 2000 & As part of merger \\
\hline Nikko Securities & Financial services & 1998-2000 & Open to employees aged $40+$ years \\
\hline Sanawa & Banking & 1999-2000 & \\
\hline $\begin{array}{l}\text { Various private } \\
\text { junior colleges }\end{array}$ & Education & $\begin{array}{l}\text { Reported March } \\
2001\end{array}$ & Falling student numbers \\
\hline
\end{tabular}

Source: Financial Times search "Top World Sources" plus Google search Japan + "early retirement".

reflecting a fear among employees that job cuts were unavoidable and such terms would not be offered a second time. ${ }^{23}$

The problems experienced by large firms had repercussions for the operation of the shukko and tenseki systems. The sectors comprising the companies receiving transferred workers suffer the same slowdown in demand growth and face the same needs to restructure, as the sector comprising the companies wishing to transfer. As a consequence, the transfer system has hit an impasse. The ability of firms to receive workers on transfer has been made worse by two further developments. First, the restructuring plans of many large firms involve them rationalizing their supply systems - Nissan, under new foreign management, was often cited as one of the leaders in this respect. Large firms have been seeking to reduce the number of sub-contractors, to enforce greater efficiency upon them and even to source from abroad. ${ }^{24}$ Second, small firms have been particularly threatened by attempts to force the banking sector to reduce bad loans - and their position is made yet weaker by the withdrawal of contracts to supply larger firms. Although such financial surgery has been performed only slowly, the number of bankruptcies has been rising. In 2000, there were 12 per cent more than in the previous year, and bankruptcies reached their highest level since 1987. Small- and medium-sized firms were hit twice over - both because the banks were putting their finances under greater scrutiny and because parent companies were seeking to extricate themselves from debt at the expense of sacrificing poorly performing subsidiaries. ${ }^{25}$

\footnotetext{
${ }^{23}$ Yomiuri Shimbun (2001), but see also the oft-described case of Japan Tobacco in Table 3. Japan Tobacco revealed that 5,800 rather than the expected 3,500 employees as having volunteered for early retirement under its cost-cutting programme (see, for example, the Associated Press report of 5-1-05).

${ }^{24}$ A study by the Mitsubishi Research Institute expected 143,000 job losses in the automobile industry of which nearly 80 per cent would be among suppliers - mainly small firms (Financial Times, 5-9-01).

${ }^{25}$ See TDB (various issues).
} 


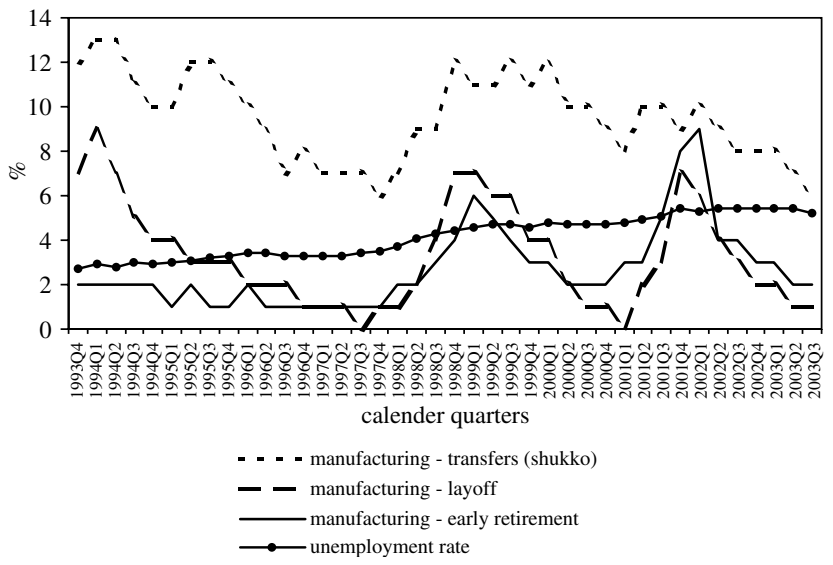

Chart 3. Share of firms reporting layoffs, transfers or early retirements. Source: Management and Co-ordination Agency, Statistics Bureau, Survey on Labour Economy Trends, quarterly. (http:// www.dbtk.mhlw.go.jp/toukei/kouhyo/data-rou15/jikei/jikeiretu-02.xls), OECD (standardized unemployment rates).

Table 4 Share of firms reporting early retirements by sector and size

\begin{tabular}{|c|c|c|c|}
\hline & 2000 & 2001 & 2002 \\
\hline All industries & 2.1 & 3.7 & 4.8 \\
\hline Manufacturing & 2.8 & 6.3 & 6.7 \\
\hline Financial services & 6.3 & 10.6 & 10.8 \\
\hline $5,000+$ employees & 13.9 & 17.6 & 19.5 \\
\hline 1,000-4,999 employees & 8.1 & 13.9 & 17.3 \\
\hline 300-999 employees & 5.1 & 6.0 & 9.7 \\
\hline 100-299 employees & 2.6 & 5.5 & 6.7 \\
\hline 30-99 employees & 1.5 & 2.6 & 3.3 \\
\hline
\end{tabular}

Source: Management and Co-ordination Agency, Statistics Bureau, Survey on employment management.

Chart 3 illustrates the trends in the incidence of layoffs, early retirements and external transfers since the mid-1990s. It reports the proportion of firms having adopted particular measures to help them adjust to downturns in demand. The overall rate of unemployment is also shown as a reference point. Although only a small minority of employers indicate they have had resort to it, the incidence of early retirement has risen substantially. At the same time, the incidence of external transfers has fallen.

It was primarily large firms that engaged in the practice of early retirement. Table 4 shows how nearly one in five of the largest offered early retirement in the year 2002 . Manufacturing firms were heavy users of early retirement, but it was by firms in the financial services sector that its use was most intense.

The struggle on the part of the government to meet demands for greater financial rectitude is likely to have a further negative impact upon the employment chances of 
older people. Table 2 showed the importance of the construction sector as an employer of older workers. This sector has been one of the principal beneficiaries of the many supplementary expenditure programmes by means of which the government has sought to sustain the "post-bubble" economy. Many public works programmes have been criticized as inefficient uses of resources and, at best, no more than a form of disguised unemployment benefit, at worst an instrument of political patronage. ${ }^{26}$ In August 2001, the government approved the "largest ever" reduction of planned expenditure - of some 2 per cent - whereby the brunt was to fall on infrastructure projects. ${ }^{27}$

Last, the ability of those sectors that have in the past absorbed some of the older people not benefiting from transfers arranged by their career employers is increasingly in doubt. International and domestic pressures have required substantial deregulation of the two other sectors critical to older people's employment - retailing and agriculture. A succession of "deregulation plans" have facilitated the opening of large supermarkets and department stores - the development of which had been impeded by local governments seeking to protect the livelihoods of small traders - and the breakdown of monopolies in the wholesale sector - over which domestic manufacturers had an effective stranglehold. If the relevant legislation is enforced, it will lead to the closure of many small shops and distribution companies currently employing older people, either on a self-employed basis or as family workers. ${ }^{28}$

Agriculture is being forced to accept WTO rulings - particularly those following the 1994 "Uruguay Round" - to open up its markets to imported rice and beef. Although agricultural employment fell by a fifth during the 1990s, the number of people aged 65 years and older at work in the sector remained almost constant, so that they made up over 40 per cent of the workforce by 1996 compared with a quarter in $1989 .^{29}$ In 1995 , the government committed itself to a 6-year programme to promote agricultural adjustment, and, as the OECD observed, "given the relatively old age of the farm labour force, most of the adjustment would be between generations". ${ }^{30}$ If agricultural reform is carried to its logical conclusion, the scope for "sheltered employment" provided by the highly regulated sector is bound to diminish rapidly.

\section{Policy responses}

Although they remain high by international standards, employment rates for older people in Japan have been falling since the late 1990s. Unemployment rates among older males were more than half as high again as the overall unemployment rates, while those for men in their early 60s exceeded 10 per cent in 1998 and only fell back to a single digit level in 2002 (Chart 4).

\footnotetext{
${ }^{26}$ See OECD (2000).

${ }^{27}$ Overall, public investment as a proportion of GDP has fallen from a peak of some 8.5 per cent in 1997 to some 4.5 per cent in 2004 (see OECD (2005, p. 86)).

${ }^{28}$ Yahata (1995).

${ }^{29}$ By 2003, people aged 65 years and over made up 47 per cent of the agricultural workforce. Since 1996 the overall agricultural workforce had fallen by nearly 20 per cent, but the number of people aged 65 years and over working in agriculture had fallen by only 5 per cent.

${ }^{30}$ OECD (1996, p. 81).
} 


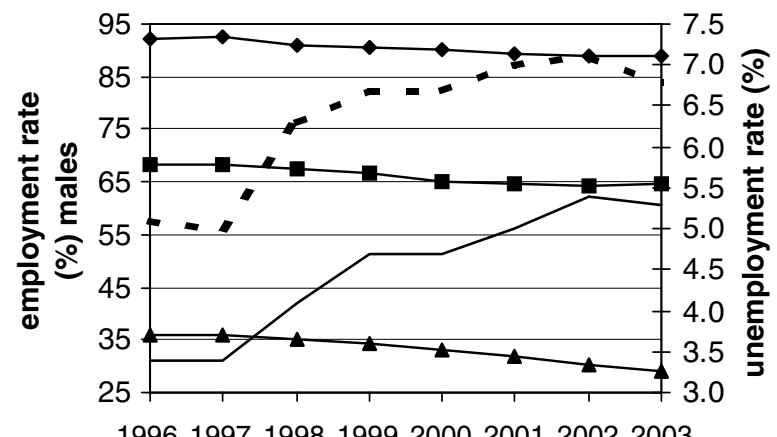

19961997199819992000200120022003

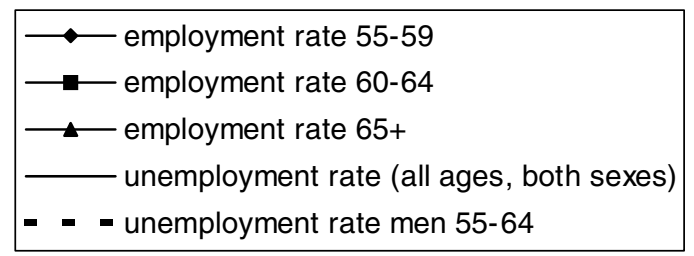

Chart 4. Trends in employment rates and unemployment rates. Source: Management and Co-ordination Agency, Statistics Bureau, Annual Report on the Labour Force Survey: 2003.

Nevertheless, a "work ethic", if this protestant concept can be applied to what is more a confucian society, continues to be strong in Japan. Older people there appear to want to work more than do older people in most many other countries. ${ }^{31}$ Indeed, the gradual decline of the lifetime employment system and, in particular, the increased incidence of redundancy and early retirement seems to have had a profound effect on the psychological well-being of older men. The increase in suicides among men in their later middle age has been remarkable, as Chart 5 testifies.

Policy actors have sought to respond in a variety of ways. Although the government had been supportive of lifting the mandatory retirement age from 55 to 60 years, it was not until 1998 that legislation prohibiting employers to operate mandatory retirement at 60 years became operative. The trade unions made the raising of the mandatory retirement age a critical element of their claims in the 2000 and 2001 wage rounds, but insofar as the government has backed them it has been through its traditional strategy of exhortation. A law on the Stabilisation of Employment of Older Persons has been revised, but this law does little more than make recommendations. Employers should make efforts to secure employment opportunities for their older employees, by taking measures for the development and improvement of occupational ability working

${ }^{31}$ An exception is the "protestant" Netherlands. According to a multi-country survey of people over 60 years carried out in the late 1980s and early 1990s, just over 70 per cent of respondents in the Netherlands said they would like to work because, otherwise, life would be too boring, and only about 20 per cent said they would like to work because they needed the money. These are the same proportions as in Japan. Elsewhere, economic concerns were much more important and the intrinsic worth of work much less important. 


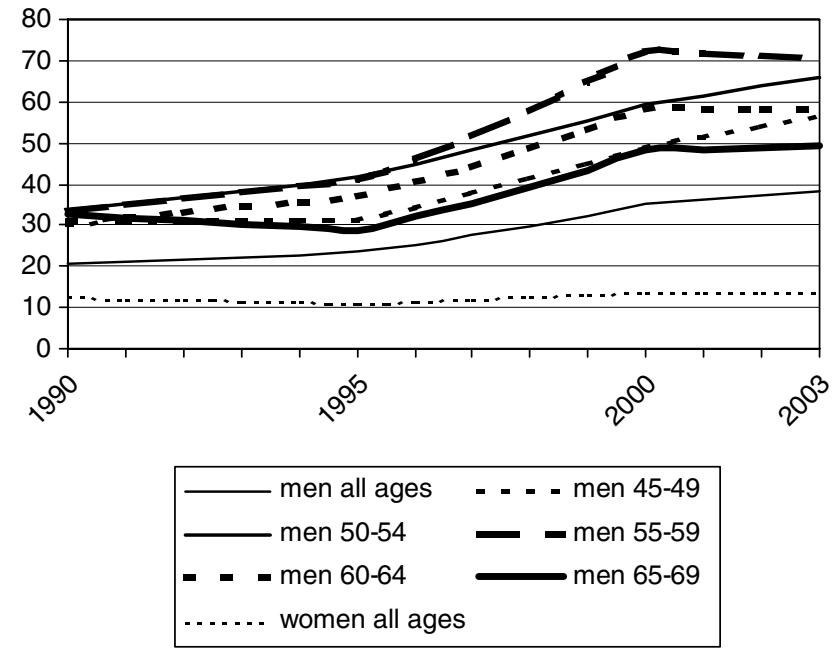

Chart 5. Trends in suicide by older men (number per 100,000). Source: Ministry of Health, Labour and Welfare, Suicide Statistics; Management and Co-ordination Agency, Statistics Bureau, Annual Report on the Labour Force Survey: 2003.

facilities and other conditions, and they should make efforts to provide necessary assistance to employees in designing an "occupational life plan" as they become older. Where they operate a mandatory retirement age, they should make efforts to adopt the necessary measures for ensuring the stable employment of older persons until the age of 65 years via the introduction or improvement of continued employment systems, and they should take measures to assist those who do leave to find alternative work.

There have been no attempts to introduce age-discrimination legislation. However, under a new provision in the Employment Measures Law that took effect in late 2001, employers are requested to make efforts to give equal opportunities regardless of age when recruiting, and a set of relevant guidelines were issued. While it seems there was some initial decrease in the use of job advertisements containing age limits, the guidelines permitted numerous exemptions. Thus, firms with a mandatory retirement system may legitimately set an age limit for recruitment on the ground that substantial training is required in the post, while those with a seniority wage system are often exempted, if they cannot hire an older person at a lower wage because of their working rules. ${ }^{32}$ Data from 2002 show 44 per cent of unemployed people aged $45-54$ years, and

\footnotetext{
${ }^{32}$ The parallels with the European Union's employment equality directive, as far as this covers age, are clear. Article 6 of this directive covers a variety of grounds under which difference of treatment on the grounds of age might be justifiable (see CEC (2000)). It might also be noted that, while Japan does have a law prohibiting discrimination on grounds of sex (but not on grounds of race), that law has been described as "lame duck" legislation (Hanami (2000)). Until 1997, the relevant law merely required that employers endeavour to offer equality of opportunity to women in recruitment and dismissal, and while it forbade discrimination with respect to training and redundancy, it gave the overseeing bodies no power to enforce their decisions (see Imada (1996); Araki (1998)).
} 
nearly 55 per cent of those aged 55 years and older, claiming that the principal reason for their failing to find work was that "I'm not in the age group qualified to apply for the job". 33

Official reports make frequent reference to how active labour market policy interventions directed at older people have been strengthened. ${ }^{34}$ For many years, the government has operated wage subsidy schemes to promote the hiring of "difficult to employ persons" - such as the elderly and the disabled - and to these have been added subsidies to employers hiring middle-aged or elderly employees in regions of high unemployment. In addition, there exists a subsidy for people taking on new work after leaving a job at 60 years that compensates for a part of the fall in wages they experience a measure that covered nearly one in 20 of those working as employees by the year 2001 . However, there appears to be no evaluation of the impact of many of these measures.

Commentators also point to how employers appear to be making some gradual changes to their employment practices. In particular, reference is made to the way in which employers claim to be planning to reduce the weight given to seniority in determining pay. The results of a survey carried out in the late 1990s, which is relatively typical of those cited, are shown in Chart 6 . However, what is to be noted is that employers are expecting greater changes to be made to wage structures for managerial grade employees than they are to those for regular employees - junior white- and blue-collar workers - who make up some five-sixths of the male labour force in the critical 45-54-year-old age group.

As far as blue-collar workers are concerned, wage adjustment through the use of employment extension schemes might be more practical. The downward adjustments associated with part-time and temporary employment are substantial. Non-standard workers have rates of pay dramatically lower than regular workers and are usually ineligible for many fringe benefits including participation in the second-tier pension. ${ }^{35}$

As well as suggestions that some consideration is being given to modifying wage systems there are also suggestions that consideration is being given to modifying promotion systems. Some employers are giving less weight to seniority in determining promotion and more to performance. The result is what are termed "out of turn" promotions. In about a third of workplaces, this is claimed to be an "every day" or "frequent" occurrence. ${ }^{36}$ Of course, where such promotions do occur, employers might experience declines in motivation among those older employees who have been passed over. Thus, they often also claim to have taken some kind of compensatory action to reassure the older people concerned. This action might or might not be cosmetic, and older employees' reported acceptance of their situation might be more or less real.

However, it is not only to their wage and promotion structures that employers need to look. In Japan, as in most other countries, firms allot a disproportionate share of training resources to younger people. This could, of itself, discourage older workers

\footnotetext{
${ }^{33}$ MHLW (2003, p. 38).

${ }^{34}$ For details see MHLW (various years) and OECD (2004).

${ }^{35}$ See Casey (2004) and OECD (2005, chapter 6).

36 JIL (2000).
} 


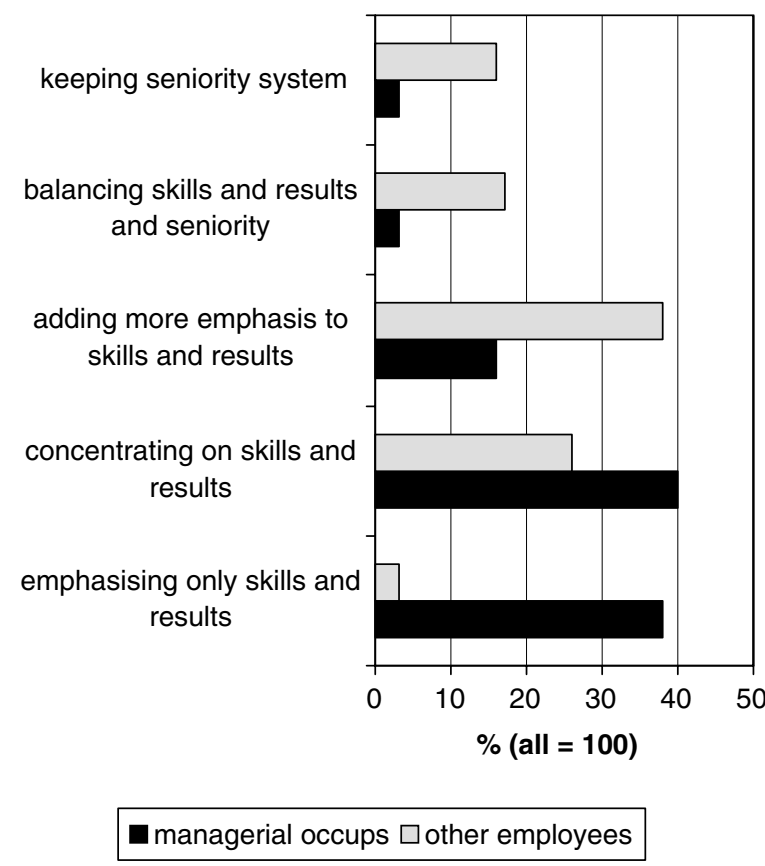

Chart 6. Employers' intentions with respect to modifying wage systems. Source: JIL, 2000.

from retraining, and might also make them unproductive workers. ${ }^{37}$ Employers in Japan seem as preoccupied as employers elsewhere with a traditional view of older persons and feel they cannot hire them because "they lose their vocational ability and flexibility as they grow older" ${ }^{38}$ The need to accommodate the ageing of the workforce, and the need to extend working life, means that resort to traditional measures for dealing with older workers - temporary extensions, downgrading and transfers - will no longer be adequate. Retraining middle-aged and older workers will become inevitable. Yet, the evidence to date is that no substantial training provision is made for older workers - except for helping them cover correspondence course fees. As an increasing number of them try to enhance their professional and technical competencies, some employers encourage middle-aged and older workers to acquire formal qualifications. However, most leave the decision to engage in such training to the workers themselves. ${ }^{39}$

\section{Conclusion}

Japan has often been suggested to be a special case. According to some commentators, the country has a distinct, perhaps unique, culture that means that there is little

\footnotetext{
37 Seike (1994).

${ }^{38}$ Wanatabe (1992).

39 Kawakita (1996).
} 
636

transferability of its experiences or practices. According to others, especially those interested in "bridge jobs", ${ }^{40}$ it is a country from which others can learn. This paper argues that Japan is, indeed, a special case, although not as special as at first might appear. However, it also argues that Japan is unlikely to be special much longer. There is little that Japan does that can be emulated, and the conditions that allowed it to be special are disappearing. At the same time, Japan is facing problems faced by many other industrialized countries. Thus, if there is something to be learned, it is not that there is something that is to be learned from Japan; indeed, it might rather be that there is something that Japan might have to learn from other countries. On the other hand, few of these countries have yet learned how to develop policies and practices that improve the "employability" of older people. All of them, and Japan as well, should still be searching vigorously for them.

\section{References}

Araki, T. (1995) 'Modification of working conditions through dismissals? A comparative analysis of the SAS case', Japan Labor Bulletin 34(8): 5-8.

Araki, T. (1998) 'Recent legislative developments in equal employment and harmonization of work and family life in Japan', Japan Labor Bulletin 37(4): 5-8.

Casey, B. (2004) The Japanese Retirement Income System: A Special Case?, Boston, MA: Centre for Retirement Research, Boston College (Global Briefing Series) (http://www.bc.edu/centers/crr/ gib_4.shtml).

CEC (2000) 'Council Directive 2000/78/EC of 27 November 2000 establishing a general framework for equal treatment in employment and occupation', Official Journal of the European Communities 2.12.2000 L 303/ 16 (http://www.europa.eu.int/comm/employment_social/fundamental_rights/pdf/legisln/2000_78_en.pdf).

Hanami, T. (2000) 'Equal employment revisited', Japan Labor Bulletin 39(1): 5-8.

Ibson, D. (2001) 'Reinventing the Japanese way of doing business: Interview with Carlos Ghosn', Financial Times, 23-07-01.

Imada, S. (1996) 'Female labor force after the enforcement of the Equal Employment Opportunity Law', Japan Labor Bulletin 35(8): 5-8.

JIL (2000) White Paper on Labour 2000, Tokyo: Japan Institute of Labour.

Kawakita, T. (1996) 'Japanese in-house training and development', Japan Labor Bulletin 35(4): 5-8.

Koike, K. (1997) Human Resource Development, Japanese Economy and Labor Series, No. 2, Tokyo: Japan Institute of Labour.

Lazear, E. (1979) 'Why is there mandatory retirement?', Journal of Political Economy 87: 1261-1284.

Lincoln, E. (2001) Arthritic Japan: The Slow Pace of Economic Reform, Washington, DC: Brookings Institution Press.

Matsuzuka, Y. (2002) Changes in the permanent employment system in Japan between 1982 and 1997, New York: Routledge.

MHLW (various years) Annual Report on Health, Labour and Welfare, Tokyo: Ministry of Health, Labour and Welfare.

OECD (1996) Economic Survey 1995-1996: Japan, Paris: Organisation for Economic Cooperation and Development.

OECD (2000) Economic Survey 1999-2000: Japan, Paris: Organisation for Economic Cooperation and Development.

OECD (2004) Ageing and Employment Policies, Japan, Paris: Organisation for Economic Cooperation and Development.

${ }^{40}$ These are the jobs, either part-time or less demanding, and often less well paid, that older people take after leaving their "career jobs" and before retiring completely, see Ruhm (1991). 
OECD (2005) Economic Survey 2005: Japan, Paris: Organisation for Economic Cooperation and Development.

Osawa, M. and Kingston, J. (1996) 'Flexibility and inspiration: Restructuring the Japanese labour market', Japan Labor Bulletin 35(1): 4-8.

Rebick, M. (1995) 'Rewards in the afterlife: Late career job placements as incentives in the Japanese firm', Journal-of-the-Japanese-and-International-Economies 9(1): 1-28.

Ruhm, C. (1991) 'Career employment and job stopping', Industrial-Relations 30(2): 193-208.

Sano, Y. (1997) 'Performance-based compensation: Individual, group and corporate level', in Y. Sano, M. Morishima and A. Seike (eds) Frontiers of Japanese Human Resource Practices, Tokyo: Japan Institute of Labour.

Sato, A. (1994) 'Employment adjustment of middle-aged and older white-collar workers', Japan Labor Bulletin 33(2): 5-8.

Sato, A. (1996) 'Keeping employees employed: Shukko and tenseki job transfers - formation of a labor market within corporate groups', Japan Labor Bulletin 35(12): 5-8.

Sato, A. (2000) 'Are Japan's small firms “ageless"”, Japan Labor Bulletin 39(5): 5-8.

Seike, A. (1994) 'The employment of older people in Japan and policies to promote it', Japan Labor Bulletin 33(12): 5-8.

TDB (various issues) Teikoku Databank bankruptcy reports, www.tdb.co.jp/english.

Wanatabe, M. (1992) 'Employment of older persons and need for support systems', Japan Labor Bulletin 31(10): 5-8.

Yahata, S. (1995) 'Ongoing price reduction and employment adjustment in the Japanese distribution sector', Japan Labor Bulletin 34(5): 5-8.

Yamada, A. (2000) 'Wage Reduction after quitting the career job: Implications for social policy', Quarterly Journal of Social Security Research (Kikan Shakai Hosho Kenkyu) 35(4): 377-394.

Yomiuri Shimbun (2001) 'More employees at major firms applying for early retirement', Yomiuri Shimbun/ Daily Yomiuri, 14-8-01.

\section{About the Author}

Bernard Casey is currently senior research fellow at The Pensions Institute, Cass Business School, London. He has been a senior economist at the OECD and has written extensively about age and employment, pensions and retirement systems, about activity in older age and about long-term care of the elderly. Much of his work has a comparative dimension. He thanks Atsuhiro Yamada, Tetsuo Ogawa and Kika Kobatake for comments and assistance at various times during the production of this paper. All interpretations and errors are, however, his own. 